\title{
Theiler's murine encephalomyelitis virus infection of astrocytes induces the expression of chemokines which attract activated but not resting T lymphocytes
}

\author{
Nazario Rubio ${ }^{1}$ (D) - Francisco Sanz-Rodriguez ${ }^{2}$ \\ Received: 5 April 2019 /Revised: 19 May 2019 / Accepted: 17 June 2019/Published online: 5 July 2019 \\ (C) Journal of NeuroVirology, Inc. 2019
}

\begin{abstract}
In this article, we studied the production of the chemokine CXCL9, also termed Mig (monokine induced by gamma interferon) by cultured SJL/J mouse astrocytes infected with the BeAn strain of Theiler's murine encephalomyelitis virus (TMEV). This picornavirus induces demyelination in the SJL/J genetically susceptible strain of mice through an immune process mediated by $\mathrm{CD}^{+} \mathrm{Th} 1 \mathrm{~T}$ cells. Those cells were chemoattracted by chemokines inside the central nervous system (CNS) after blood-brain barrier (BBB) disruption.

cRNAs from TMEV- and mock-infected astrocytes cells were hybridized to the Affymetrix murine genome U74v2 DNA microarray. Hybridization data analysis revealed the upregulation of six sequences potentially coding for Mig. We confirmed post infection Mig mRNA increase by quantitative (qPCR) and RT-PCR. The presence of Mig in the supernatants of infected astrocytes was quantified using a specific ELISA. Secreted Mig was biologically active, inducing chemoattraction of mouse activated $\mathrm{CD}^{+} \mathrm{T}$ lymphocytes. Conversely, attracting activity on $\mathrm{CD}^{+}$resting $\mathrm{T}$ cells that can be attributed to chemokines as CXCL12/SDF-1 $\alpha$ could not be demonstrated in these supernatants. No overinduction of the gene coding for this chemokine was assessed by DNA hybridization either. Both recombinant IFN- $\gamma$ and TNF- $\alpha$ inflammatory cytokines were also strong inducers of Mig in SJL/J astrocyte cultures.
\end{abstract}

Keywords Chemokines $\cdot$ CXCL9/Mig $\cdot$ Astrocytes $\cdot$ T lymphocytes $\cdot$ Neuroinflammation $\cdot$ Multiple sclerosis

$\begin{array}{ll}\text { Abbreviations } \\ \text { Mig } & \text { Monokine induced by gamma interferon } \\ \text { TMEV } & \text { Theiler's murine encephalomyelitis virus } \\ \text { CNS } & \text { Central nervous system } \\ \text { BBB } & \text { Blood-brain barrier } \\ \text { DMEM } & \text { Dulbecco's Modified Eagle Medium } \\ \text { m.o.i } & \text { Multiplicity of infection } \\ \text { PFU } & \text { Plaque-forming units } \\ \text { GFAP } & \text { Glial fibrillary acidic protein } \\ \text { MBP } & \text { Myelin basic protein } \\ \text { MS } & \text { Multiple sclerosis }\end{array}$

Nazario Rubio nazario@ cajal.csic.es

1 Instituto Cajal. C.S.I.C, Dr. Arce Avenue 37, 28002 Madrid, Spain

2 Department of Biology, Universidad Autonoma de Madrid, Madrid, Spain

\section{Introduction}

Acute neuroinflammation occurs in response to damage due to infection or tissue injury. During this process, cellular factors induce the recruitment of circulating immune cells into the central nervous system. These cells upregulate their expression of immunological signals, recruiting additional cells. This feedback expression of low levels of these immune molecules over long periods of time promotes various pathological effects, including demyelination. Main cytokines regulating inflammatory response include (1) interleukins that are responsible for communication between lymphocytes, (2) chemokines that promote chemotaxis, and (3) interferons with an anti-viral effect. During the past years, we have studied the overinduction of those immune mediators in the majority of the glial cell population, the astrocytes, as a consequence of its infection by the demyelinating Theiler's virus.

Theiler's murine encephalomyelitis virus (TMEV) is a picornavirus that persistently infects mice (Theiler 1937). The intracerebral infection of its low-neurovirulence BeAn strain in demyelination-susceptible strains of mice (including SJL/J 
and SJL/H strains) is currently used as an experimental model for studying human demyelination processes such as multiple sclerosis (MS). Animals that survive the acute phase disease develop chronic demyelination. This is followed by lymphoid cell infiltration into the brain, a delayed type hypersensitivity reaction (DTH) and myelin destruction (Lipton and Dal Canto 1976; Clatch et al. 1986; Roos et al. 1982).

In the present article, we focused on the overexpression of the "activated T lymphocytes-attracting chemokine" (CXCL9) or "monokine induced by gamma interferon" (Mig), in pure cultures of astrocytes infected by TMEV. We have also demonstrated the absence of expression of chemokines reported so far to attract resting-naïve $\mathrm{T}$ cells (5 belonging to the CC family, 1 to the CXC family, and 2 to the C family) (Bajetto et al. 2002; Systematic nomenclature for chemokines 1999).

An increase in the CXCL9 response after coronavirus retinopathy infection has been previously reported (Detrick et al. 2008). This chemokine, also expressed in mouse brain endothelial cells (Ghersa et al. 2002), plays an important role in the defense of the host against several viral infections and allograph rejection (Koga et al. 1999) and lymphocyte proliferation (Whiting et al. 2004). The expression of several chemokines different to CXCL9 following TMEV infection has been reported by Palma and Kim (2004), Rubio and SanzRodriguez (2007), and Rubio et al. (2014). Its expression in multiple sclerosis lesions has also been demonstrated (Simpson et al. 2000; Sørensen et al. 1999).

\section{Materials and methods}

Methods were similar to those previously described in Rubio and Sanz-Rodriguez (2007) and Rubio et al. (2014) and then briefly summarized here.

\section{Astrocyte cell cultures}

Astrocyte cultures were prepared by mechanical dissociation of the cerebral cortex of newborn SJL/J Harlan mice (Rubio et al. 2003). All animals were maintained on standard feed and provided water ad libitum at the Instituto Cajal. The cortex was isolated under a dissecting microscope and cleaned of the choroid plexus and meninges. Cell suspensions were filtered through a $135-\mu \mathrm{m}$ pore mesh into Dulbecco's Modified Eagle Medium (DMEM) containing 10\% fetal calf serum (FCS) and gentamicin (Gibco BRL, Paisley, Scotland). After centrifugation, cell suspensions obtained were filtered through a $40-\mu \mathrm{m}$ nylon cell strainer (Falcon-Becton Dickinson, Le Pont De Claix, France) and then cultured in $75-\mathrm{cm}^{2}$ tissue culture flasks (Costar, Cambridge, MA) at $37{ }^{\circ} \mathrm{C}$. Cultures were enriched for astrocytes by removal of fewer adherent cells by shaking overnight at $37^{\circ} \mathrm{C}$ at $250 \mathrm{rpm}$ in a tabletop shaker
(Thermo Forma, Marietta, OH). A mean of $98 \%$ astrocytes was confirmed by indirect immunofluorescence staining of methanol-fixed cultures using rabbit anti-glial fibrillary acidic protein (GFAP) antiserum (Dakopatts, Glostrup, Denmark).

\section{Viruses and infection}

For these studies, the BeAn 8386 strain of TMEV, isolated in 1957 from a feral mouse in Belem, Brazil, was used. Baby hamster kidney cells (BHK-21) were grown at $37{ }^{\circ} \mathrm{C}$ in DMEM containing $10 \%$ FCS and penicillin-streptomycin. BHK-21 cultures were infected for $48 \mathrm{~h}$ at $33^{\circ} \mathrm{C}$, sonicated, and centrifuged in the cold to remove cell debris. Purified astrocytes in $75-\mathrm{cm}^{2}$ tissue culture flasks were infected with the virus at several multiplicities of infection $(\mathrm{MOI}=0.1,1$, and 10 ) in a volume of $10 \mathrm{~mL}$ of DMEM containing $0.1 \%$ BSA at room temperature for $1 \mathrm{~h}$. The percentage of cells infected in almost $100 \%$ at a MOI of 10 . Cells used for mock infections controls were incubated with a virus-free BHK-21 cell lysate.

\section{CRNA target preparation and DNA hybridization}

Three replicates of SJL/J astrocyte cultures mock infected or infected at a m.o.i of 10 were harvested $8 \mathrm{~h}$ post infection (p.i.) and washed with phosphate-buffered saline (PBS), and the total RNA was isolated by using TRIzol reagent (Gibco BRL). This was followed by further purification using the RNeasy Mini purification kit (Qiagen, Valencia, CA.). Ten micrograms of RNA from each culture was converted to cDNA using the SuperScript Choice System kit (Gibco BRL). The second-strand synthesis was performed using T4 DNA polymerase, and cDNA was isolated by phenolchloroform extraction. The cDNA isolated was transcribed using the BioArray High Yield RNA Transcript Labeling Kit (Enzo Biochem, New York, NY) with biotin-labeled UTP and CTP to produce biotin-labeled cRNA. The cRNA was isolated using the RNeasy Mini Kit and fragmented for $30 \mathrm{~min}$ at $94{ }^{\circ} \mathrm{C}$ in a buffer containing $100 \mathrm{mM}$ potassium acetate, $30 \mathrm{mM}$ magnesium acetate, and $40 \mathrm{mM}$ Tris-acetate ( $\mathrm{pH}$ 8.1). The hybridization performance was analyzed using 2 arrays (Affymetrix, Santa Clara, CA) with spike and housekeeping controls. The target cRNA was hybridized to the murine genome U74v2 microarray (Affymetrix) following the manufacturer's recommendations.

\section{RT-PCR analysis}

Total RNA from mock- or TMEV-infected astrocyte cultures and from mouse brains was purified using the RNeasy Mini purification kit (Qiagen). Samples were reverse transcribed using Moloney murine leukemia virus reverse transcriptase (RT) (Promega, Madison, WI) and the $3^{\prime}$ amplimer as a 
template/primer. The primers used for CXCL9/Mig amplification (Liu et al. 2001) were designed according to the results of a Primer-BLAST analysis and synthesized by SigmaAldrich, Tres Cantos, Madrid, Spain.

5': (5'-CGTCGTCGTTCAAGGAAG-3').

3': (5'-TCGAAAGCTTGGGAGGTT-3').

A primer set for mouse $\beta$-actin, used as a housekeeping positive control, was also supplied by Sigma-Aldrich:

5': (5'-GTG GGC CGC CCT AGG CAC CA-3').

3': (5'-CTC TTT GAT GTC ACG CAC GAT TTC-3').

The cycling conditions for the RT-PCR reactions were 30 cycles at $94{ }^{\circ} \mathrm{C}$ for $1 \mathrm{~min}$ followed by $1 \mathrm{~min}$ at $60^{\circ} \mathrm{C}$ plus $1 \mathrm{~min}$ at $72{ }^{\circ} \mathrm{C}$ and a final $10 \mathrm{~min}$ extension period at $72{ }^{\circ} \mathrm{C}$. All reactions were run on a Perkin Elmer Cetus 480 DNA thermocycler, and the resulting PCR products were purified using S-400 MicroSpin columns (Pharmacia Biotech, Uppsala, Sweden). After electrophoresis in 2\% NuSieve agarose gels (FMC Bio Products, Rockland, ME) in TAE buffer, the bands produced were stained with ethidium bromide and photographed in a Gelstation system (TDI, Barcelona, Spain). The DNA molecular weight markers VIII (Roche Diagnostics GmbH, Manheim, Germany) were used.

\section{Quantitative real-time PCR}

Total RNA was extracted from mock- or TMEV-infected astrocytes using the RNeasy Mini purification kit (Qiagen), and cDNA was prepared from RNA using Moloney murine leukemia virus reverse transcriptase (RT) from Promega Corp. (Madison, WI) using the $3^{\prime}$ primer as a template/primer. Primers were the same as used for RT-PCR. Quantitative PCR was performed using a ABI PRISM 7000 Sequence Detector System (Applied Biosystems, Weiterstadt, Germany) following the manufacturer's recommendations.

\section{ELISA determination of CXCL9}

Enzyme-linked immunoassays (ELISA) were performed using the Quantikine ${ }^{\circledR}$ Immunoassay kit for mouse CXCL9/ Mig (R\&D Systems, Minneapolis, MN). It has a limit of detection of $1.2-4.2 \mathrm{pg} / \mathrm{mL}$, and there is no cross-reactivity with other chemokines such as KC, IP10, or SDF- $1 \alpha$.

\section{Neutralizations by specific antibodies}

BeAn virus samples were incubated with increasing dilutions of rabbit antisera to purified TMEV viral particles at $37{ }^{\circ} \mathrm{C}$ for $30 \mathrm{~min}$ (Clatch et al. 1987). Thereafter, the incubation mixtures were used for infection of astrocyte cultures. At $10^{-2}$ and $10^{-3}$ dilutions, $100 \%$ of astrocytes became infected, $50 \%$ at $10^{-4}$ and less than $2 \%$ at $10^{-5}$ and $10^{-6}$ dilutions as determined by virus titration. Antiserum against $\mathrm{CsCl}$-purified adenovirus
Ad. $\beta$ Gal was used as a negative neutralization control (Rubio and Martin-Clemente 2002).

\section{Migration assay for T lymphocytes}

For the resting $\mathrm{T}$ lymphocyte migration assay, peripheral blood from germ-free SJL/J mice anesthetized with Fluothane ${ }^{\circledR}$ was collected into EDTA-containing tubes by retro-orbital puncture. After sterile red blood cell lysis in $150 \mathrm{mM}$ Tris, $20 \mathrm{mM}$ ammonium chloride, $\mathrm{pH}$ 7.2, cells were washed twice in the medium. Cell viability ( $>96 \%$ ) was assessed by trypan blue exclusion.

In the activated $\mathrm{T}$ cell migration assay, a variant of the murine $\mathrm{CD}^{+} \mathrm{T}$ helper cell clone $\mathrm{D} 10$ (Ojeda et al. 1995) that is continuously activated in the presence of IL-2 was used. These cells were maintained in Click's EHAA medium (Gibco BRL) supplemented with 10\% FCS and 5 I.U./mL of recombinant IL-2 (Hoffman-La Roche Inc. Nutley, NJ). The D 10 cells were washed and resuspended in (DMEM) medium, with no detectable loss of viability.

Chemotactic assays were conducted in the upper chamber of Transwell chambers with $5-\mu \mathrm{m}$ pore size membranes (Costar, Cambridge, MA). The cells were quantified using flow cytometry (Coulter EPICS-XL). For resting T cells, an anti-CD3 antibody was used, and for the activated $\mathrm{CD}^{+} \mathrm{T}$ helper cells (clone D 10) an anti-CD4 antibody, both from BD Biosciences-Pharmingen, San Diego, CA. An irrelevant P3X63 mAb was used for negative control staining (not shown).

\section{Cytokines treatment}

Astrocytic cells in culture were treated for $1 \mathrm{~h}$ at $37^{\circ} \mathrm{C}$ with $10 \mathrm{ng} / \mathrm{mL}$ of the following mouse recombinant proinflammatory cytokines: mouse recombinant IL- $1 \alpha$ (Genzyme, Cambridge, MA); recombinant interferon- $\gamma$ (IFN- $\gamma)$ (Holland Biotechnology, Leiden, The Netherlands); recombinant murine tumor necrosis factor- $\alpha$ (TNF- $\alpha$ ) (Innogenetics, Antwerp, Belgium); and recombinant IL-6 (Boehringer Mannheim, Germany). After treatment, the supernatants were tested for the presence of Mig using the aforementioned ELISA.

\section{Results}

\section{Microarray analysis of gene expression in infected cells}

Perturbation of cell regulation is a characteristic of viral infections, including TMEV infection. The purpose of our studies using Affymetrix mouse GeneChip ${ }^{\circledR}$ DNA hybridization is to 
study the transcriptional response of TMEV-infected primary cultures of astrocytes from SJL/J mice.

Eight hours after TMEV infection, Affymetrix GeneChip SE437 and SE438 microarray expression analysis showed 533 sequences being upregulated (red circles) and 1440 downregulated (blue circles) in the $\mathrm{SJL} / \mathrm{J}$ astrocyte genome. Furthermore, 10,449 sequences were unchanged. The maximum fold increase for upregulated genes was 37.6, and 16.6 was the maximum fold decrease for the downregulated ones. All those data were summarized in Fig. 1.

Six sequences with a UniGene database hit description of "interferon gamma-induced protein" hybridized with TMEVinfected astrocyte RNA but not, or only marginally, with sham-infected astrocyte RNA (sequences 100,981 at and 103,639 at). These upregulated target sequences have signal $\log 2$ ratios of 7.5-3.3 and were located on mouse chromosomes number 1, 7, 11, and 19, as shown in Table 1.

\section{CXCL9/Mig mRNA in astrocytes}

The results of the microarray analysis were validated by those provided by RT-PCR and qPCR. Total RNA was isolated from infected astrocytes, and increases in its specific expression were determined. Mouse CXCL9/Mig primer pairs were used for RT-PCR amplification in cultures infected with the BeAn viral strain at m.o.i 0 (mock infection) to 10 . Clear bands were detected in cultures infected at m.o.i of 1 or 10 , but no bands were found in uninfected cultures (Fig. 2a). $\beta$-actin was used as a positive housekeeping control (lower panel).

qPCR, a sensitive technique for nucleic acids quantification, showed mRNA syntheses at m.o.i of 1-10 to be 12- and 18 -fold higher than those found in mock-infected cells $(P<0.05)$ (Fig. 2 bA). A kinetics study demonstrated that Mig production increased slowly $2-4 \mathrm{~h}$ after infection, reaching maximum levels after $8 \mathrm{~h}$ (Fig.2 bB). The above

\section{SE438 (TMEV-infected) vs SE437 (mock-infected)} microarray

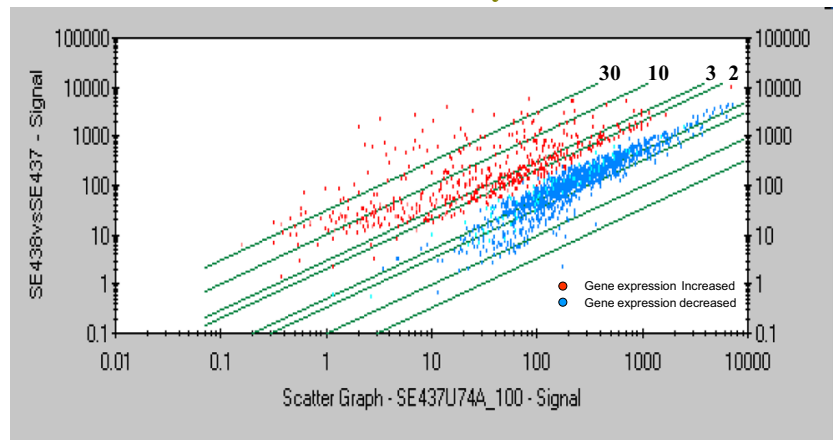

Fig. 1 Scatter graph showing the gene expression signals increased (red circles) and decreased (blue circles) after infection with TMEV. The regression lines $(30,10,3$, and 2$)$ represent changes in the intensity of each transcript results clearly show that astrocytes express Mig de novo as a consequence of TMEV infection.

\section{Alignment analysis}

In order to further determine if the Affymetrix main sequence used (104,750 at) matches the Mig National Center Biological Information (NCBI) Genbank sequence, we performed an alignment analysis using the LALIGN program from the European Molecular Biology Laboratory-European Bioinformatics Institute (EMBL-EBI).

Negative control was provided by the alignment between the Affymetrix sequence 104,750 at with the unrelated gene of human serum albumin (NCBI Genbank accession number: V004951.1) which produces a $27.3 \%$ identity.

When we compared the main sequence with the mouse Mig NCBI GeneBank accession number: M34815.1 sequence, we obtained a $94.9 \%$ identity. These data demonstrated that our reactions were detecting Mig RNA and that the Affymetrix sequence matches the mouse Mig sequence.

\section{ELISA determination of Mig}

Supernatants of astrocytic cells from $\mathrm{SJL} / \mathrm{J}$ mice showed a statistically significant increase in Mig production when infected at m.o.i. 1-10 in ELISA assay, as determined by using the Quantikine ${ }^{\mathrm{R}}$ mouse Mig ELISA (Fig. 3a). Maximum production was $100 \mathrm{pg} / \mathrm{mL}$ at a m.o.i of 10 . No Mig activity can be found in supernatants from mock-infected cultures (Fig. 3a, 0 ). Analysis of the production kinetics by cells infected at m.o.i of 10 indicates maximal chemokine release into the supernatant after $24 \mathrm{~h}$ (Fig. 3b). Mig production is reflective of the number of astrocytes actually infected.

\section{Antibody neutralization}

We ruled out the possibility that some factors present in the BHK-21 homogenates, used as TMEV stocks, might induce the activity studied. A rabbit anti-TMEV antiserum, containing antibodies to VP-1 and VP-2 capsid proteins (Clatch et al. 1987), was used in the blocking of Mig induction experiments. Incubation with increasing antiserum dilutions prevented the presence of Mig activity in the supernatants, as detected by ELISA (Fig. 4b). Antibody binding to the viral capsid proteins sterically inhibited BeAn virion binding to its receptors as, for instance, is the case for human rhinovirus-14 (Smith 2002). An anti-Ad.ßGal adenovirus rabbit antiserum provides negative control, lacking any inhibitory action on the induction capacity of TMEV (Fig. 4b).

Anti Mig antibodies produced a plateau of inhibition of $32 \% \pm 3.27 \%$ activity (Fig. $4 a$ ). So, this value seems to be the contribution of Mig in the mixture of activated T cell- 
Table 1 Induced upregulation of sequences annotated as belonging to "interferon gamma-induced/ inducible proteins" or to "interferon gamma-activated gene" in the UniGene database. All changes were significant based on the triplicate analysis of the signal log ratio

\begin{tabular}{|c|c|c|c|c|c|c|}
\hline $\begin{array}{l}\text { Afymetrix } \\
\text { sequence }\end{array}$ & $\begin{array}{l}\text { Sham- } \\
\text { infected } \\
\text { astrocytes } \\
\text { signal }\end{array}$ & $\begin{array}{l}\text { TMEV- } \\
\text { infected } \\
\text { astrocytes } \\
\text { signal }\end{array}$ & $\begin{array}{l}\text { Signal } \\
\log \\
\text { ratio }\end{array}$ & $\begin{array}{l}\text { Fold } \\
\text { change }\end{array}$ & $\begin{array}{l}\text { Chromosome } \\
\text { location }\end{array}$ & UniGene title \\
\hline 104,750 at & $\begin{array}{l}2.3 \\
\text { Absent }\end{array}$ & $\begin{array}{l}681.8 \\
\text { Present }\end{array}$ & 7.5 & 15.0 & 11 & $\begin{array}{l}\text { Interferon } \\
\text { gamma-inducible } \\
\text { protein }\end{array}$ \\
\hline 103,432 at & $\begin{array}{l}3.7 \\
\text { Absent }\end{array}$ & $\begin{array}{l}427.1 \\
\text { Present }\end{array}$ & 6.5 & 13.0 & 7 & $\begin{array}{c}\text { Interferon stimulated } \\
\text { protein }(20 \mathrm{KDa})\end{array}$ \\
\hline 100,981 at & $\begin{array}{l}72.1 \\
\text { Present }\end{array}$ & $\begin{array}{l}3060.4 \\
\text { Present }\end{array}$ & 5.1 & 10.2 & 19 & $\begin{array}{l}\text { Interferon induced } \\
\text { protein with } \\
\text { tetratricopeptide } \\
\text { repeats } 1\end{array}$ \\
\hline 103,639 at & 80.2 Present & $\begin{array}{l}2809.9 \\
\text { Present }\end{array}$ & 4.8 & 9.6 & 19 & $\begin{array}{l}\text { Interferon induced } \\
\text { protein with } \\
\text { tetratricopeptide } \\
\text { repeats } 2\end{array}$ \\
\hline 94,774 at & $\begin{array}{l}44.0 \\
\text { Absent }\end{array}$ & $\begin{array}{l}662.0 \\
\text { Present }\end{array}$ & 4.1 & 8.2 & 1 & $\begin{array}{l}\text { Interferon activated } \\
\text { gene } 202 \mathrm{~A}\end{array}$ \\
\hline 97,409 at & $\begin{array}{l}40.8 \\
\text { Absent }\end{array}$ & $\begin{array}{l}465.4 \\
\text { Present }\end{array}$ & 3.3 & 6.6 & 11 & $\begin{array}{l}\text { Interferon inducible } \\
\text { protein } 1\end{array}$ \\
\hline
\end{tabular}

attracting chemokines contained in our supernatants. An anti-CXCL1/KC goat IgG antibody was used as a negative control (Fig. 4a).

Thus, a specific Mig activity was found in the supernatants, possibly mixed with other chemokines that attract activated T cells, as CXCL10/IP10 (Rubio et al. 2014). Those biological activity results confirmed the molecular and immunological findings previously presented in this article.

\section{Biological chemoattracting activity of astrocyte supernatants}

We next compared by flow cytometry the chemoattracting activity of TMEV-infected astrocytes supernatants on resting $\left(\mathrm{CD}^{+}\right)$or activated $\left(\mathrm{CD}^{+}\right) \mathrm{T}$ lymphocytes. As shown in Fig. 5, those supernatants attracted activated (murine CD4 ${ }^{+}$ $\mathrm{T}$ helper D10 cell line) but not resting T cells (peripheral blood lymphoid cells from germ-free SJL/J mice). The conclusion of

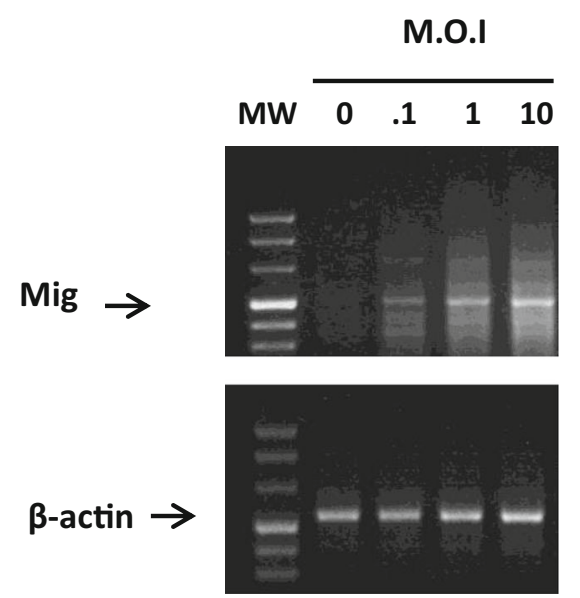

a

Fig. 2. a Expression of Mig mRNA in TMEV-infected astrocytes. Upper panel: RNA from mock-infected (0) cells or cells infected at m.o.i of 0.1 and 1 . RNA purification was performed $8 \mathrm{~h}$ after infection and afterwards reverse transcribed and PCR amplified using specific mouse Mig primer pairs. Lower panel: $\beta$-actin primers were used as a housekeeping gene positive control. Lane MW: DNA molecular weight markers. b Boxplot of Mig mRNA synthesis assessed by quantitative real-time qPCR after

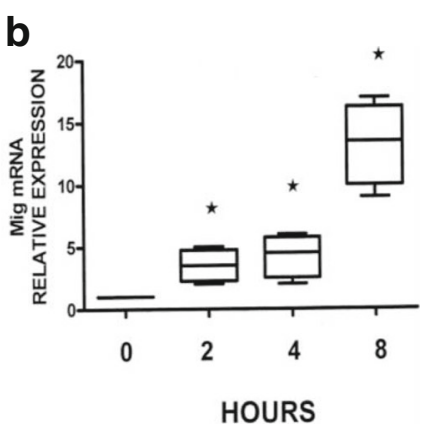

infection at different m.o.i for $8 \mathrm{~h}$ (B) or at different times with a common m.o.i of 10 (A). The lower boundary of the boxes represents the 25th percentile, the upper boundary the 75th, and the line inside the box is the 50th percentile. *Statistically significant differences with the mockinfected cultures ( 0 ), assigned a value of 1 , as determined by Student's $t$ test $(P<0.01)$ 


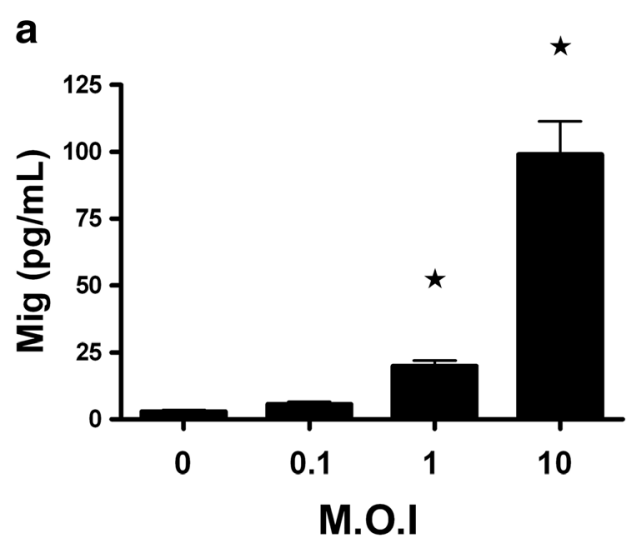

Fig. 3 Mig levels in TMEV-infected astrocyte culture supernatants quantified by ELISA. a Supernatants from mock-infected astrocytes $(0)$ or from cells infected at m.o.i of $0.1-10$ were tested $24 \mathrm{~h}$ after infection. b The kinetics of Mig production was measured from 0 (mock infection) to

this assay is the demonstration of the presence of an activated T cell-attracting and the absence of a resting $T$ cell-attracting activity in the supernatants. Very interestingly, the cells triggering the DTH reaction producing demyelination in the TMEV system were also of the $\mathrm{CD} 4^{+} \mathrm{T}$ helper phenotype (Clatch et al. 1986) Fig 6.

In order to assess the absence of chemoattraction for resting $\mathrm{T}$ cells, we looked for sequences coding for resting $\mathrm{T}$ cellattracting chemokines in the overall 533 sequences upregulated after TMEV infection. We only found one reference to these genes, coding for the stromal cell-derived factor- $1 \alpha$, SDF- $1 \alpha /$ CXCL12, that, as a matter of fact, was absent in both mock- and TMEV-infected astrocytes (Table 2).

\section{Mig induction by cytokines}

Several inflammatory cytokines are known to activate astrocytes and upregulate expression of chemokines and other immune molecules. The results of four recombinant inflammatory cytokines on the induction of Mig in astrocytes were

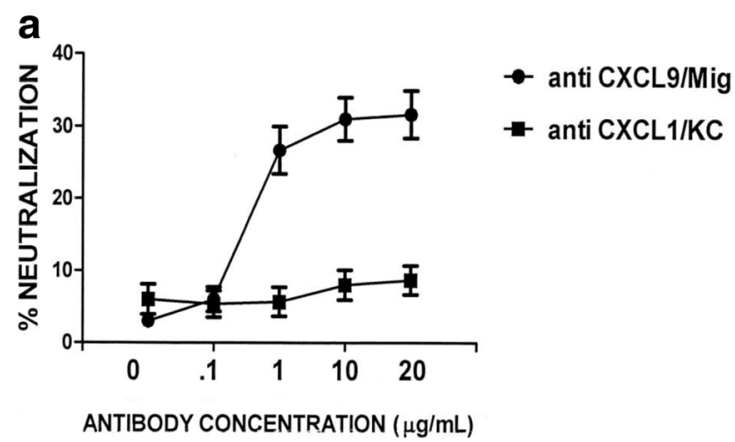

Fig. 4 a Inhibition of the Mig chemoattracting activity by anti CXCL9/ Mig or negative control anti CXCL1/KC antibodies. Samples of supernatants containing around $100 \mathrm{pg} / \mathrm{mL}$ of Mig, according to ELISA readings, were incubated with different concentrations of antibodies and the remaining chemotactic activity tested afterwards. b Viral specificity test for TMEV-induced Mig induction. TMEV samples equivalent to m.o.i. of

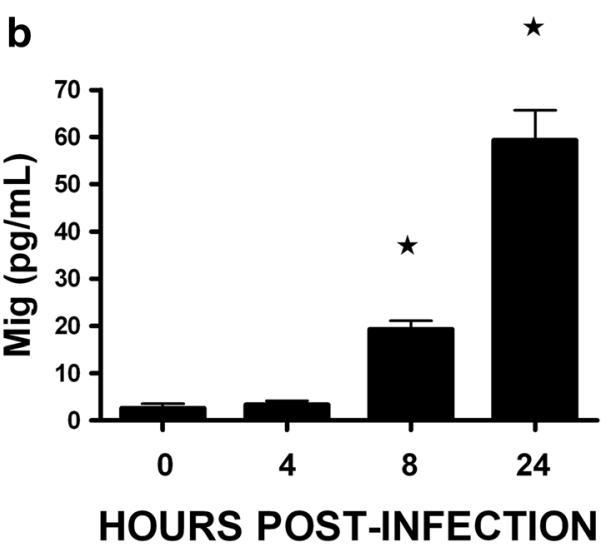

$24 \mathrm{~h}$ post infection at a m.o.i of 10 . Results represent mean values \pm SD of triplicate samples. *Significant differences with the mock-infected control group $(0)$ were determined by Student's $t$ test $(P<0.01)$

summarized in Table 3. TNF- $\alpha(100 \mathrm{pg} / \mathrm{mL})$ and IFN- $\gamma$ $(430 \mathrm{pg} / \mathrm{mL})$ induced a statistically significant secretion of the chemokine into the culture supernatants $(P<0.01)$. IFN- $\gamma$ is the stronger inducer as the name of the chemokine suggested (Mig: monokine induced by gamma interferon). Conversely, exposure to the interleukins IL- $1 \alpha$ and IL- 6 did not trigger any upregulation of the Mig molecule. In Table 3, we have summarized our previous results on this field (Rubio and Sanz-Rodriguez 2007; Rubio et al. 2014). TNF- $\alpha$ is shown to be the best inducer ( 4 chemokines) followed by IL- $1 \alpha$ (3) and IFN- $\gamma$ (2). IL-6 does not induce any chemokine in astrocyte cultures. The induction of Mig by IFN- $\gamma$ is 4 and 3 times stronger $(430 \mathrm{pg} / \mathrm{mL})$ than TMEV infection $(100 \mathrm{pg} /$ $\mathrm{mL}$ at a m.o.i of 100).

\section{Discussion}

Here, we have presented an overview of the total changes in $\mathrm{SJL} / \mathrm{J}$ astrocytes gene expression due to TMEV infection

b

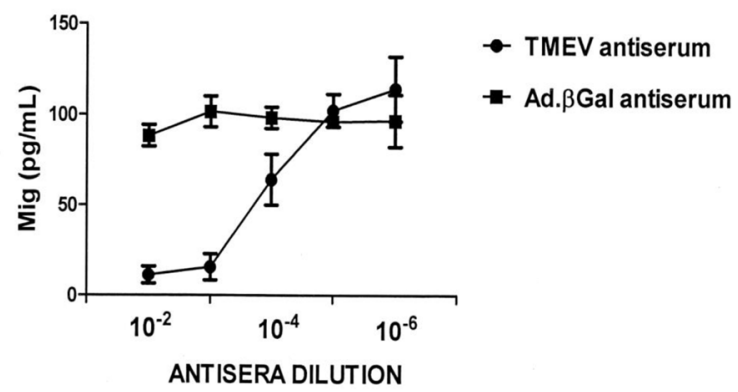

10 were incubated at $37{ }^{\circ} \mathrm{C}$ for 30 min with different dilutions of antiTMEV or anti-adenovirus Ad. $\beta$ Gal antisera and afterwards added to the astrocyte cultures. After $24 \mathrm{~h}$ of incubation, the presence of Mig in the supernatants was monitored by ELISA. Data represent the mean $\pm \mathrm{SD}$ of triplicate samples. The average results from three representative experiments are shown 


\section{Resting $\mathrm{CD}^{+}{ }^{+} \mathrm{T}$ cells}

Activated $\mathrm{CD}^{+}{ }^{+} \mathrm{T}$ cells

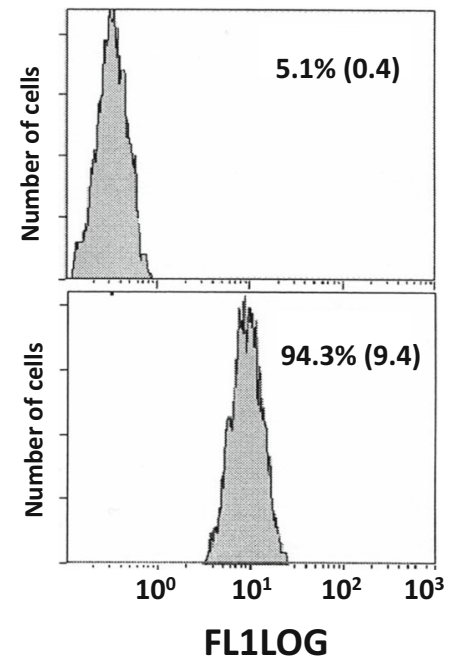

Fig. 5 Flow cytometry analysis of the T lymphocytes chemoattracting activity of supernatants from TMEV-infected astrocytes. Peripheral blood from germ-free $\mathrm{SJL} / \mathrm{J}$ mice was used to obtain resting $\mathrm{T}$ cells (upper panel). The Il-2-treated T helper cell clone D 10 cells were used as activated cells (lower panel). Cells migrate across $5-\mu \mathrm{m}$ pore size Transwell chambers. Anti-CD3 antibodies were used to stain resting T cells and antiCD4 for activated T cells. The relative proportion of stained cells is indicated, followed by the mean fluorescence intensity (in parentheses) in the upper corners of the quadrant

(Fig. 1) and then we have studied the changes in the expression of a particular one (Mig, Table 1).

According to its chemoattracting capacity, the CXC family of chemokines is divided into two subfamilies. The first one, to which $\mathrm{CXCL} 12 / \mathrm{SDF}-1 \alpha$ belongs, regulates the migration of naive $\mathrm{T}$ lymphocytes to secondary lymphoid tissues for

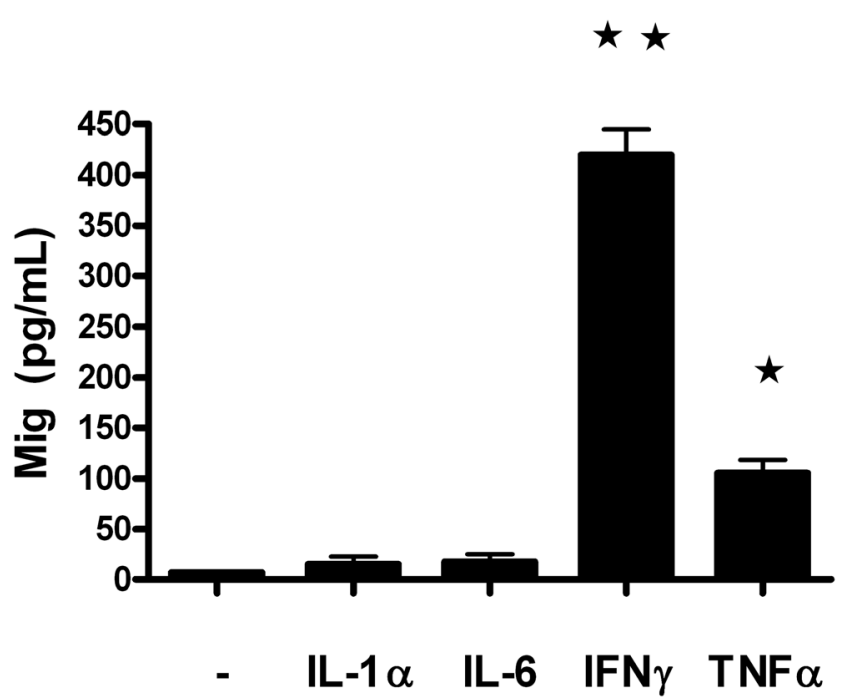

Fig. 6 Induction of Mig in astrocytes by inflammatory cytokines treatments. Astrocytic cultures were untreated $(-)$ or treated with $10 \mathrm{ng} /$ $\mathrm{mL}$ of each recombinant IL- $1 \alpha$, IL- 6 , IFN- $\gamma$, and TNF- $\alpha$, during a period of $48 \mathrm{~h}$. Supernatants were then centrifuged and tested for the presence of Mig by ELISA. Data represent the mean \pm SD of triplicate samples. *Significant differences with the untreated control groups $(-)$ were determined by Student's $t$ test $(P<0.01)$ activation (Kim and Broxmeyer 1999). The second one, comprising the chemokines CXCL10/IP10 and CXCL9/Mig, induces the trafficking of activated antigen-specific $\mathrm{T}$ cells to virus-infected inflammation sites (Dufour et al. 2002). The members of this second subfamily are critical for the control of infections, including corneal or genital herpes simplex virus infections (Thapa et al. 2008; Wuest et al. 2006), as well as for T cell-mediated suppression of cutaneous tumors (Gorbachev et al. 2007). Members of this family also contribute to the protective $\mathrm{T}$ cell response of the CNS against mouse hepatitis virus infection in C57BL/mice (Liu et al. 2001). In a situation of strong neuroinflammation, as our experimental model of TMEV-produced MS-like syndrome in mice, a clear role for chemokines inducing the recruitment of specific $\mathrm{CD} 4^{+} \mathrm{T}$ cells to sites of inflammation inside the CNS should be expected. In the present study, we experimentally show that chemokines of this class (Mig) are synthesized by TMEV-infected astrocyte in culture.

Mig is a member of the CXC chemokines family that induces both $\mathrm{NK}$ and activated $\mathrm{CD} 4^{+} \mathrm{T}$ cells migration and thus participates in the host defense against viral infections through the interaction with its CXCR3 receptor (Farber 1997; Mahalingam et al. 1999). The production of Mig by astrocytes in vitro predicts the recruitment of TMEV-specific activated T cells in vivo, after crossing the BBB. Therefore, Mig could play an important role in the immunological mechanisms that induce demyelination by inducing this kind of traffic towards the site of infection inside the nervous system.

Using hybridization to the U74v2 DNA microchip array from Affymetrix, we demonstrated the overexpression of genes coding for putative Mig in murine astrocytes infected with the BeAn virus. The DNA hybridization results were further validated by RT-PCR and qPCR (Fig. 2). Both techniques confirmed an increase in mRNA when using Migspecific primers. A biologically active Mig chemokine, which can be detected and quantified by a specific ELISA assay (Fig. 3 ), is released to the culture medium by infected astrocytes. A clear chemoattraction effect for activated T cells was demonstrated in the supernatants of infected astrocyte cultures (Fig. 5). Specifically, the murine $\mathrm{CD}^{+} \mathrm{T}$ helper cell clone D10, which is continuously activated in the presence of recombinant IL-2 (Ojeda et al. 1995), was strongly chemoattracted by these supernatants. Conversely, no activity due to chemokines attracting resting $\left(\mathrm{CD}^{+}\right) \mathrm{T}$ lymphocytes was detected in the supernatants studied. These experimental facts demonstrate that the chemoattracting mediators produced in this system are specific for activated $\mathrm{T}$ cells and not for naive or resting $\mathrm{T}$ cells.

So far, several chemokines have been shown to be induced in SJL/J astrocytes by TMEV infection: CXCL2/MIP-2 and CXCL1/KC (Rubio and Sanz-Rodriguez 2007), CXCL10/IP10 (Rubio et al. 2014), and CXCL9/Mig (this article). Our results demonstrate that both neutrophils, chemoattracted by 
Table 2 Stromal cell-derived factor (SDF-1 $\alpha$ ) gene, as annotated in the UniGene, PFAM, and SCOP databases, is not expressed (Absent) in either sham- or TMEV-infected astrocytes

\begin{tabular}{|c|c|c|c|c|c|c|}
\hline & $\begin{array}{l}\text { Sham-infected } \\
\text { astrocytes signal }\end{array}$ & $\begin{array}{l}\text { TMEV-infected } \\
\text { astrocytes signal }\end{array}$ & $\begin{array}{l}\text { Chromosome } \\
\text { location }\end{array}$ & UniGene & PFAM ${ }^{*}$ & $\mathrm{SCOP} * *$ \\
\hline $\begin{array}{c}162,234 \\
\text { f at }\end{array}$ & $\begin{array}{l}1.2 \\
\text { Absent }\end{array}$ & $\begin{array}{l}29.4 \\
\text { Absent }\end{array}$ & $\# 6$ & $\begin{array}{l}\text { Stromal cell-derived } \\
\quad \text { factor } 1\end{array}$ & $\begin{array}{l}\text { Small } \\
\text { cytokine/- } \\
\text { chemokine }\end{array}$ & $\begin{array}{l}\text { Stromal cell-derived factor } \\
\quad(\text { SDF-1 } \alpha)\end{array}$ \\
\hline
\end{tabular}

MIP-2 and KC, and activated T lymphocytes, attracted by IP10 and Mig, are the first immune cells migrating inside the CNS after infection.

In addition, we report in this study that Mig is induced after treatment with cytokines that are usually involved in immunemediated inflammatory processes, such as IFN- $\gamma$ and TNF- $\alpha$ (Rubio and Sanz-Rodriguez 2007). In Table 3, we summarize the induction of the chemokines by those inflammatory cytokines as the results of several years of study. These results indicate that TNF- $\alpha$ is the more efficient inducer of chemokines, followed by IL- $1 \alpha$ and IFN- $\gamma$, which induce three and two of the chemokines studied, respectively. In contrast, the cytokine IL-6 does not have any effect on SJL/J astrocytes. The amounts of chemokine proteins secreted by stimulated astrocytes were many-fold higher than the background of uninfected controls (average $20 \mathrm{pg} / \mathrm{mL}$ ).

We can speculate that the production of Mig and IP10 by astrocytes in vitro predicts the recruitment of TMEV-specific activated $\mathrm{CD}^{+}$Th1 $\mathrm{T}$ lymphocytes, which cross the disrupted $\mathrm{BBB}$ in vivo. These cells, as well as other mononuclear cells, such as macrophages, can cause demyelination by a nonspecific bystander effect, resulting in the stripping of myelin lamellas.

The upregulation of Mig in the CNS of TMEV-infected mice has been probed (Pachner et al. 2015), and the neutralization of Mig increases virus antigen expressión and spinal cord

Table 3 Induction of members of the CXC chemokine ligand family in $\mathrm{SJL} / \mathrm{J}$ astrocytes following treatment with several recombinant inflammatory cytokines. In parenthesis, the mean concentration of chemokines in the supernatants (in $\mathrm{pg} / \mathrm{mL}$ ) induced by the different cytokines at a concentration of $10 \mathrm{ng} / \mathrm{mL}$ during $48 \mathrm{~h}$

\begin{tabular}{ll} 
Inducer cytokine & SJL/J astrocytes-induced chemokine \\
\hline TNF- $\alpha$ & KC/CXCL1 $(7000 \mathrm{pg} / \mathrm{mL})$ \\
& MIP-2/CXCL2 $(1200 \mathrm{pg} / \mathrm{mL})$ \\
& Mig/CXCL9 $(100 \mathrm{pg} / \mathrm{mL})$ \\
& IP-10/CXCL10 $(17,000 \mathrm{pg} / \mathrm{mL})$ \\
IL-1 $\alpha$ & KC/CXCL1 $(20,000 \mathrm{pg} / \mathrm{mL})$ \\
& MIP-2/CXCL2 $(1500 \mathrm{pg} / \mathrm{mL})$ \\
& IP-10/CXCL10 $(17,000 \mathrm{pg} / \mathrm{mL})$ \\
IFN- $\gamma$ & Mig/CXCL9 $(430 \mathrm{pg} / \mathrm{mL})$ \\
& IP-10/CXCL10 $(17,000 \mathrm{pg} / \mathrm{mL})$ \\
IL-6 & - \\
\hline
\end{tabular}

pathology. Recent results suggest that Mig participates in the immune response that restricts TMEV expression and therefore limited immunopathology (Ure et al. 2005).

The clear cut in vitro results presented here mean that the astrocyte, the major population on glial cells in the brain, can be one of the cells responsible for Mig synthesis in vivo after TMEV infection.

Acknowledgments We thank Dr. Jose M. Rojo, Centro de Investigaciones Biologicas, C.S.I.C, Madrid, Spain, for providing the D10 cell line.

*PFAM, Protein FAMily database; **SCOP, Structural Classification Of Proteins database

\section{References}

Bajetto A, Bonavia R, Barbero S, Schettini G (2002) Characterization of chemokines and their receptors in the central nervous system: physiopathological implications. J Neurochem 82:1311-1329

Clatch RJ, Lipton HL, Miller SD (1986) Characterization of Theiler's murine encephalomyelitis virus (TMEV)-specific delayed-type hypersensitivity responses in TMEV-induced demyelinating disease: correlation with clinical signs. J Immunol 136:920-927

Clatch RJ, Pevear DC, Rozhon E, Roos RP, Miller SD, Lipton HL (1987) Characterization and specificity of humoral immune response to Theiler's murine encephalomyelitis virus capsid proteins. J Gen Virol 68:3191-3196

Detrick B, Lee MT, Chin MS, Hooper LC, Chan CC, Hooks JJ (2008) Experimental coronavirus retinopathy (ECOR): retinal degeneration susceptible mice have an augmented interferon and chemokine (CXCL9, CXCL10) response early after virus infection. J Neuroimmunol 193:28-37

Dufour JH, Dziejman M, Lui MT, Leung JH, Lane TE, Luster AD (2002) IFN-gamma-inducible protein 10 (IP-10; CXCL10)-deficient mice reveal a role for IP-10 in effector T cell generation and trafficking. J Immunol 168:3195-3204

Farber JM (1997) Mig and IP-10: CXC chemokines that target lymphocytes. J Leukoc Biol 61:246-257

Ghersa P, Gelati M, Coline J, Feger G, Power C, Papoian R, Salmaggi A (2002) MIG differential gene expression in mouse brain endothelial cells. Neuroreport. 13:9-14

Gorbachev AV, Kobayashi H, Kudo D, Tannenbaum Ch S, Finke JH, Shu S, Farber JM, Fairchild RL (2007) CXC chemokine ligand 9/ monokine induced by IFN- $\gamma$ production by tumor cells is critical for T cell-mediated suppression of cutaneous tumors. J Immunol 178:2278-2286

Kim CH, Broxmeyer HE (1999) Chemokines: signal lamps for traficking of T and B cells for development and effector functions. J Leukoc Biol 65:6-15 
Koga S, Auerbach MB, Engenman TM, Novick AC, Toma H, Fairchild RL (1999) T cell infiltration into class II MHC-disparate allografts and acute rejection is dependent on the IFN-gsmms-induced chemokine Mig. J Immunol 163:4878-4885

Lipton HL, Dal Canto M (1976) Theiler's virus induced demyelination: prevention by immunosuppression. Science. 192:62-64

Liu MT, Armstrog D, Hamilton TA, Lane TE (2001) Expression of Mig (monokine induced by interferon-gamma) is important in T lymphocyte recruitment and host defense following viral infection of the central nervous system. J Immunol 166:1790-1795

Mahalingam S, Farber JM, Karupiah G (1999) The interferon-inducible chemokines MuMig and Crg-2 exhibit antiviral activity in vivo. J Virol 73:1479-1491

Ojeda G, Ronda M, Ballester S, Diez-Orejas R, Feito MJ, Gracía-Albert L, Rojo JM, Portoles P (1995) A hyperreactive variant of a CD4 ${ }^{+} \mathrm{T}$ cell line is activated by syngeneic antigen presenting cells in the absence of antigen. Cell Immunol 164:265-278

Pachner AR, Li L, Gilli F (2015) Chemokine biomarkers in central nervous system tissue and cerebrospinal fluid in the Theilers virus model mirror those in multiple sclerosis. Cytokine. 76:577-580

Palma JP, Kim BS (2004) The scope and activation mechanisms of chemokine gene expression in primary astrocytes following infection with Theiler's virus. J Neuroimmunol 149:121-129

Roos RPSF, Wollmann R, Variakojis D, Arnason BGW (1982) The effect of short-term and chronic immunosuppression on Theiler's virus demyelination. J Neuroimmunol 2:223-234

Rubio N, Martin-Clemente B (2002) Binding of adenovirus to its receptors in mouse astrocytes induces c-fos proto-oncogene and apoptosis. Virology. 297:211-219

Rubio N, Sanz-Rodriguez F (2007) Induction of CXCL1 (KC) chemokine in mouse astrocytes by infection with the murine encephalomyelitis virus of Theiler. Virology. 358:98-108

Rubio N, Martin-Clemente B, Lipton HL (2003) High- neurovirulence GDVII virus induces apoptosis in murine astrocytes through tumor necrosis factor (TNF)-receptor and TNF-related apoptosis induced ligand. Virology. 311:366-375

Rubio N, Arévalo M-A, Cerciat M, Sanz-Rodriguez F, Unkila M, GarciaSegura LM (2014) Theiler's virus infection provoques the overexpression of genes coding for the chemokine IP10 (CXCL10) in SJL/
J murine astrocytes, which can be inhibited by modulators of estrogen receptors. J Neurovirology 20:485-495

Simpson JE, Newcombe J, Cuzner ML, Woodroofe MN (2000) Expression of the interferon-gamma-inducible chemokines IP-10 and Mig and their receptor, CXCR3, in multiple sclerosis lesions. Neuropathol Appl Neurobiol 26:133-142

Smith TJ (2002) Antibody interactions with Rhinoviridae, p 39-49. In: Semler BL, Wimmer E (eds) Molecular biology of picornaviruses. ASM Press, Washington D.C

Sørensen TL, Tani M, Jensen J, Pierce V, Lucchinetti C, Folcik VA, Qin S, Rottman J, Sellebjerg F, Strieter RM, Frederiksen JL, Ransohoff RM (1999) Expression of specific chemokines and chemokine receptors in the central nervous system of multiple sclerosis patients. J Clin Invest 103:807-815

Systematic nomenclature for chemokines. (1999). Peprotech EC. www. peprotechecec.com

Thapa M, Welner RS, Pelayo R, Carr DJ (2008) CXCL9 and CXCL10 expression are critical for control of genital herpes simplex virus type 2 infection through mobilization of HSV-specific CTL and Nk cells to the nervous system. J Immunol 180:1098-1106

Theiler M (1937) Spontaneous encephalomyelitis of mice, a new virus disease. J Exp Med 65:705-719

Ure DR, Lane TE, Lui MT, Rodríguez M (2005) Neutralization of chemokines RANTES and MIG increases virus antigen expressión and spinal cord pathology during Theiler's virus infection. Int Immunol 17(5):569-579

Whiting D, Hsieh G, Yun JJ, Banerji A, Yao W, Fishbein MC, Belperio J, Strieter RM, Bonavida B, Ardehali A (2004) Chemokine monokine induced by IFN-gamma/CXC chemokine ligand 9 stimulates $\mathrm{T}$ lymphocyte proliferation and effector cytokine production. J Immunol 172:7417-7424

Wuest T, Farber J, Luster A, Carr DJ (2006) CD4+T cell migration into the cornea is reduced in CXCL9 deficient but not CXCL10 deficient mice following herpes simplex virus type 1 infection. Cell Immunol 243:83-89

Publisher's note Springer Nature remains neutral with regard to jurisdictional claims in published maps and institutional affiliations. 